\title{
Effect of Seeds Size on Germination of Faba Bean Plant
}

\author{
Noha Fahad Alngiemshy ${ }^{1}$, Jana Saleh Alkharafi ${ }^{1}$, Norah Saud Alharbi ${ }^{1}$, Noorah Saleh Al-Sowayan ${ }^{2 *}$ \\ ${ }^{1}$ Department of Biology, College of Science, Qassim University, Buraydah, Saudi Arabia \\ ${ }^{2}$ Department of Biology, Faculty of Science, Qassim University, Buraydah, Saudi Arabia \\ Email: ^nsaoiean@qu.edu.sa, knaaj1@yahoo.com
}

How to cite this paper: Alngiemshy, N.F., Alkharafi, J.S., Alharbi, N.S. and Al-Sowayan, N. S. (2020) Effect of Seeds Size on Germination of Faba Bean Plant. Agricultural Sciences, 11, 465-471.

https://doi.org/10.4236/as.2020.115028

Received: March 28, 2020

Accepted: April 26, 2020

Published: April 29, 2020

Copyright () 2020 by author(s) and Scientific Research Publishing Inc. This work is licensed under the Creative Commons Attribution International License (CC BY 4.0).

http://creativecommons.org/licenses/by/4.0/

(c) (i) Open Access

\begin{abstract}
The study was conducted in Al-Qassim region in February 2020 and the study aimed to know the effect of seed size on germination and some morphological parameters in Faba bean (Vicia faba L.) plant, by dividing the seeds into three sizes large $2.5-2.3 \mathrm{~cm}$, medium $2.0-2.2 \mathrm{~cm}$, and small $1.7-1.9 \mathrm{~cm}$ and planting them. The results showed that the germination percentage in the large seeds was the highest (100\%), and the size of the seeds affected the length of the root and shoot as the large seeds gave the highest length for root $(8.37 \mathrm{~cm})$ and shoot $(14.2 \mathrm{~cm})$ compared to the medium and small seeds. So, for these results, the seed size is closely related to root and shoot length, number of leaves.
\end{abstract}

\section{Keywords}

Faba Bean, Seed Size, Germination

\section{Introduction}

Faba bean (Vicia faba L.) is also known as broad bean one of the most important crops in the world, and fourth on the level of legumes in importance [1] [2], and it is being grown around the world as a food source [3]. The central habitat of faba bean plant is the Middle East, where legumes are generally a staple food there. Their high protein content can be replacement meat for reduced income people [3] [4]. They also are cover crops that improve soil fertility and play an important role in nitrogen fixation, because of their symbiosis between faba bean and Rhizobium bacteria. Furthermore, the other plants can benefit from this [5] [6].

The seeds defined as a young embryonic plant in the state of dormancy, and when factors are available, they sprout. Some environmental conditions such as oxygen, temperature, light, and water required for seed germination [7], but there 
is a factor for the size of the seed that affects germination rates and speed, which is one of the most important factors affecting seed growth [8], germination speed, crop strength, and seed vigor [9], seed classification according to their size are popular methods in agriculture, as many scientists agree that the seed size is associated with increased growth and the strength of the crop. Therefore, it is essential to know the effect of seed size on germination.

The seeds affect the germination percentage at the time of germination; the seed size in legumes affects cereal production [10]. Usually, small seeds are germination faster, but larger seeds have a higher germination rate and higher growth and greater yield [1] due to the availability of more food, and it is known that the amount of food is related to the size of the seeds [11]. There is a positive relationship between seed size and seedling growth [12] and also in crop improvement [10]. The amount of starch varies due to the different seed sizes, and the amount of starch may be associated with germination [13].

It has observed that there is an effect on the difference in the size of Afzelia africana seeds on germination [14]. This study aims to investigate the effect of faba bean seed size on the germination percentage and some growth vigor of the plant.

\section{Materials and Methods}

\subsection{Experimental Site}

The experiment conducted in the Qassim region located in the north-central of the Kingdom of Saudi Arabia between February and March 2020. The total precipitation rain was $0 \mathrm{~mm}$, and the average temperature was $20^{\circ} \mathrm{C}$.

\subsection{Experiment Design and Treatments}

The soil used in the experiment was sandy. Seeds Vicia faba L. obtained from the seed market in the Qassim region. Seeds were divided manually into three groups by using the ruler based on length and width; the large seeds ranged between 2.5 - $2.3 \mathrm{~cm}$, the medium seeds ranged between $2.0-2.2 \mathrm{~cm}$, and the small seeds ranged between $1.7-1.9 \mathrm{~cm}$ was 20 large Seeds, 20 medium seeds and 20 small Seeds. The groups were soaked in water from the tap for 24 hours separately. After that, they germinated in sterile Petri dishes on filter paper moistened with water. Petri dishes were put in the dark at a temperature of $25^{\circ} \mathrm{C}$ for seven days and during these days get wet with water.

The sand soil filled in the 30 plastic packages $(12 \mathrm{~cm}$ in diameter and $9 \mathrm{~cm}$ in height) that have perforated holes in the base to drain the excess water by $15 \mathrm{~g}$ per package, then the germinated seeds were planted at a depth of $3.0 \mathrm{~cm}$ and watering once a day after two-week was calculated germination percentage according to the following equation

$$
\text { Germination percentage } \%=\frac{\text { number of germinated seeds }}{\text { number of total seeds planted }} \times 100 \text { [9] }
$$

Moreover, it took root length, shoot length, and the number of leaves. 


\subsection{Data Analysis}

The analysis of variance was carried out for the results using the least significant difference (LSD) at 0.05 probability levels.

\section{Results}

\subsection{Germination Percentage}

Seed germination is mainly affected by the seed size. A study has carried out on three different seed sizes: small, medium, and large. 100\% of the large size seeds appeared at the end of the experiment, while the medium and the small size seeds had a lower appearance percentage of $85 \%$ and $70 \%$, respectively. The seeds size also affects the apparition of seedlings. In the study, the large and medium size seeds took four days to appear, while the small size seeds took only two days to appear.

\subsection{Root and Shoot Length}

The study shows that the root length was affected by the size of the seed. The root length of the large seeds is longer than the other seeds, and the root of the medium seeds was longer than the small seeds' roots, as presented in Figure 1 and Figure 2. While Table 1 shows that there are significant differences $(\mathrm{P} \leq$ 0.05 ) between the root lengths of the large seeds and the medium seeds and between the large seeds and the small seeds and between the medium seeds and the small seeds.

Similarly, for the shoot length, as shown in Figure 2 and Figure 3, the shoot lengths of the large seeds were longer than the others, and the shoots of the medium seeds were in between them. The significant differences $(P \leq 0.05)$, as shown in Table 1, were found between all seed sizes.

\subsection{Number of Leaves}

The number of leaves varied according to the size of the seed. There is a positive relationship between seed size and the number of leaves, as shown in Figure 4.

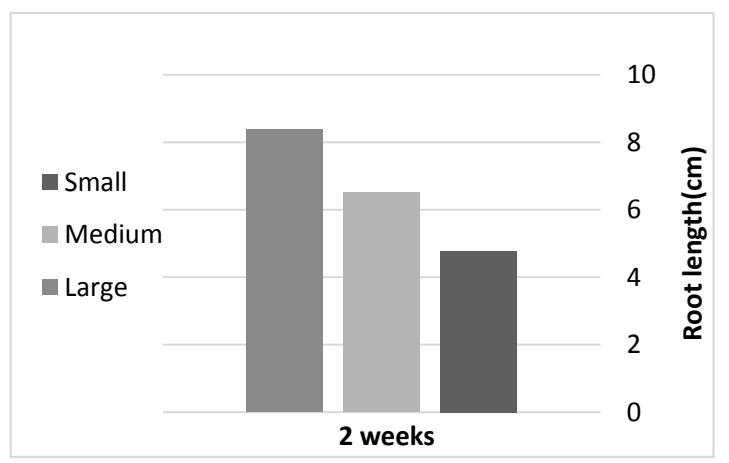

Figure 1. The root length $(\mathrm{cm})$ of faba bean plant after two weeks from planting. 


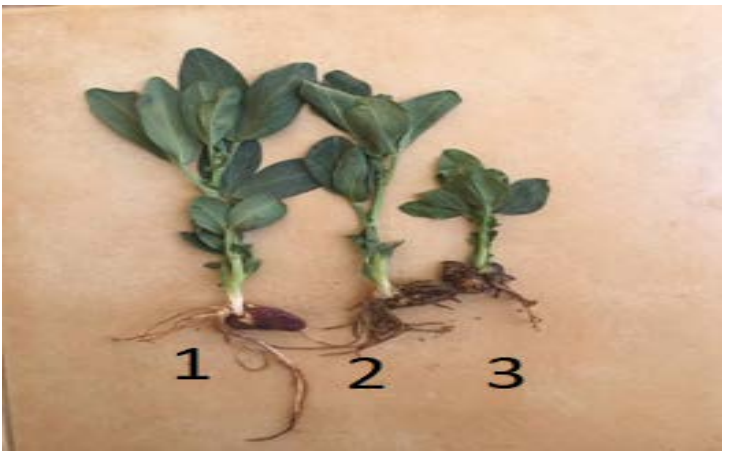

Figure 2. 1: Seedlings of large seed; 2: Seedlings of medium seed; 3: Seedling the smallseed. After two weeks from planting.

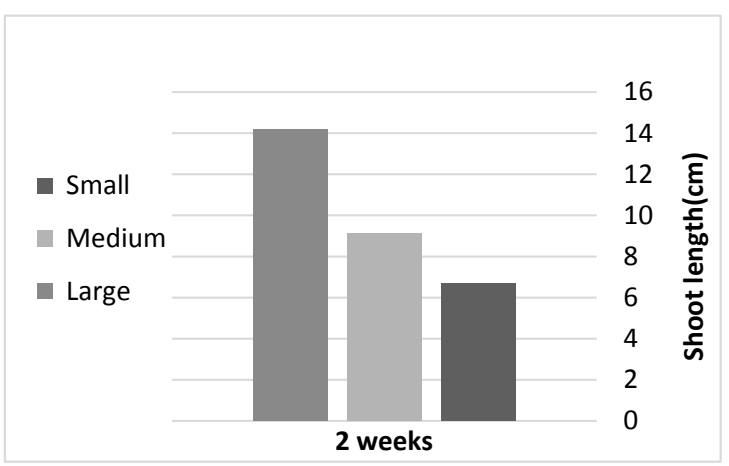

Figure 3. The shoot length $(\mathrm{cm})$ of faba bean plant after two weeks from planting.

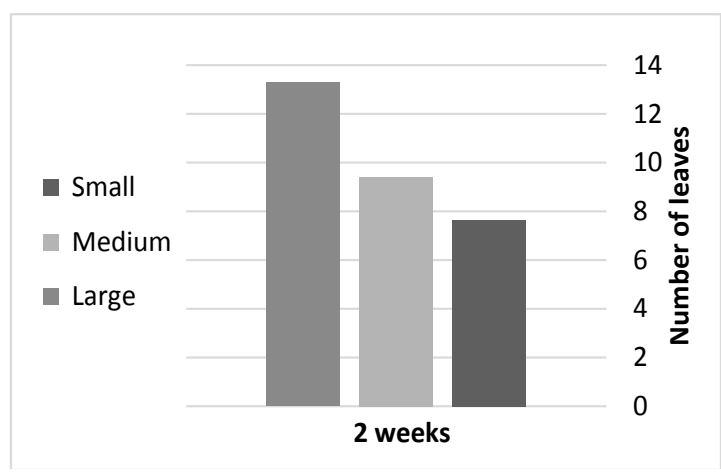

Figure 4. The number of leaves of faba bean plant after two weeks from planting.

Table 1. Effect of seed size on root length $(\mathrm{cm})$, shoot length $(\mathrm{cm})$ and number of leaves.

\begin{tabular}{cccc}
\hline Seed size & Root length $(\mathrm{cm})$ & Shoot length $(\mathrm{cm})$ & Number of leaves \\
\hline Large & 8.37 & 14.2 & 13.3 \\
Meduim & 6.5 & 9.1 & 9.4 \\
Small & 4.8 & 6.4 & 7.6 \\
LSD (P $\leq 0.05)$ & 1.13 & 1.98 & 3.12 \\
\hline
\end{tabular}


The large seeds have more leaves than the other seeds, while the medium seeds have a lower number of leaves than the large seeds and more than the small ones. The significant effect $(P \leq 0.05)$ on the number of leaves is similar to the root length and shoot length, as shown in Table 1, found significant differences between all seed sizes.

\section{Discussion}

Morphological parameters of faba bean plants, such as root length, shoot length, and the number of leaves, appear higher in plants grown from large seeds compared to plants with other seed sizes. Small seeds germinate faster than medium and large seeds, so there is an inverse relationship between germination speed and seed size. The smaller the size of the seeds, the faster the germination. The result is consistent with this research [7] on Prosopis africana seeds. The germination percentage in large seeds was higher than medium and small seeds, there consistent with [15], but there was no effect of the difference in the size of wheat seeds in the germination percentage [9].

This study showed that the length of roots is affected by the size of the seeds, similar to the research [8], where the roots in large seeds were much longer than small seeds and medium seeds. The result indicates that the seed size affects the root length. Larger seed size may have resulted in higher germination due to increased endosperm.

There is a difference between the plant length; it is clear that the shoot length is also the effect by seed sizes, a decrease in the shoot length with a decrease in the seed size similar to the research [8] [16], so the shoot length was shorter with small seeds than the shoot length in large and medium seeds, maybe that large seeds because they have more energy stored to support the seedling growth.

Large seeds produce more leaves than medium and small seeds. Hence, there is a correlation between faba bean seed size and the number of leaves, and the results of the study are in accordance with [16] in seeds peanuts and Sunflower in [17].

\section{Conclusion}

Results of the current work revealed that the germination percentage in the case of small seeds was faster than that of medium and large seeds, but the large seeds give seedlings longer than medium and small seeds. The results indicate that the size of seeds affects the germination percentage and the length of seedlings. Thus, seed size has a role in improving seed germination.

\section{Conflicts of Interest}

The authors declare no conflicts of interest regarding the publication of this paper. 


\section{References}

[1] Al-Rifaee, M.O.H.D., Turk, M.A. and Tawaha, A.R.M. (2004) Effect of Seed Size and Plant Population Density on Yield and Yield Components of Local Faba Bean (Vicia faba L. Major). International Journal of Agriculture and Biology, 6, 294-299.

[2] López-Bellido, F.J., López-Bellido, L. and López-Bellido, R.J. (2005) Competition, Growth and Yield of Faba Bean (Vicia faba L.). European Journal of Agronomy, 23, 359-378. https://doi.org/10.1016/j.eja.2005.02.002

[3] Etemadi, F., Hashemi, M., Zandvakili, O. and Mangan, F.X. (2018) Phenology, Yield and Growth Pattern of Faba Bean Varieties. International Journal of Plant Production, 12, 243-250. https://doi.org/10.1007/s42106-018-0023-1

[4] Qabil, N., Helal, A.A., El-Khalek, A. and Rasha, Y.S. (2018) Evaluation of Some New and Old Faba Bean Cultivars (Vicia faba L.) for Earliness, Yield, Yield Attributes and Quality Characters. Zagazig Journal of Agricultural Research, 45, 821-833. https://doi.org/10.21608/zjar.2018.49119

[5] Pereira, S., Mucha, Â., Goncalves, B., Bacelar, E., Látr, A., Ferreira, H., Oliveira, I., Rosa, E. and Marques, G. (2019) Improvement of Some Growth and Yield Parameters of Faba Bean (Vicia faba) by Inoculation with Rhizobium laguerreae and Arbuscular Mycorrhizal Fungi. Crop \& Pasture Science, 70, 595-605. https://doi.org/10.1071/CP19016

[6] Kharrat, M., Ben Salah, H. and Halila, H.M. (1991) Faba Bean Status and Prospects in Tunisia. In: Cubero, J.I. and Saxena, M.C., Eds., Present Status and Future Prospects of Faba Bean Production and Improvement in the Mediterranean Countries, CIHEAM, Zaragoza, 169-172.

[7] Dera, B.A., Agera, S.I.N. and Ezugwu, E.U. (2019) Effect of Seed Size and Acid Scarification on Germination and Early Growth of Prosopis africana. Journal of Global Biosciences, 8, 5774-5788.

[8] Ali, S.A. and Idris, A.Y. (2015) Effect of Seed Size and Sowing Depth on Germination and Some Growth Parameters of Faba Bean (Vicia faba L.). Agricultural and Biological Sciences Journal, 1, 1-5.

[9] Baysah, N.S., Olympio, N.S. and Asibuo, J.Y. (2018) Influence of Seed Size on the Germination of Four Cowpea (Vigna unguiculata (L) Walp) Varieties. ISABB Journal of Food and Agricultural Sciences, 8, 25-29. https://doi.org/10.5897/ISABB-JFAS2017.0075

[10] Adebisi, M.A., Kehinde, T.O., Salau, A.W., Okesola, L.A., Porbeni, J.B.O., Esuruoso, A.O. and Oyekale, K.O. (2013) Influence of Different Seed Size Fractions on Seed Germination, Seedling Emergence and Seed Yield Characters in Tropical Soybean (Glycine max L. Merrill). International Journal of Agricultural Research, 8, 26-33. https://doi.org/10.3923/ijar.2013.26.33

[11] Souza, M.L. and Fagundes, M. (2014) Seed Size as Key Factor in Germination and Seedling Development of Copaifera langsdorffii (Fabaceae). American Journal of Plant Sciences, 5, 2566-2573. https://doi.org/10.4236/ajps.2014.517270

[12] Neugschwandtner, R.W., Papst, S., Kemetter, J., Wagentristl, H., Sedlář, O. and Kaul, H.P. (2019) Effect of Seed Size on Soil Cover, Yield, Yield Components and Nitrogen Uptake of Two-Row Malting Barley. Die Bodenkultur. Journal of Land Management, Food and Environment, 70, 89-98. https://doi.org/10.2478/boku-2019-0008

[13] Ahirwar, J.R. (2012) Effect of Seed Size and Weight on Seed Germination of Alangium lamarckii, Akola, India. Research Journal of Recent Sciences, 1, 320-322. 
[14] Folake, A.B. and Olusola, O.A. (2020) Effect of Seed Size on Afzelia africana (Smith) Germination. International Journal of Agriculture, Forestry and Fisheries, 8, 1.

[15] Umeoka, N. and Ogbonnaya, C.I. (2016) Effects of Seed Size and Sowing Depth on Seed Germination and Seedling Growth of Telfairia occidentalis (Hook F.). International Journal of Advances in Chemical Engineering \& Biological Sciences, 3, 201-207. https://doi.org/10.15242/IJACEBS.AE0916207

[16] Olayinka, U.B., Owodeyi, S.O. and Etejere, E.O. (2016) Biological Productivity and Composition of Groundnut in Relation to Seed Size. Environmental and Experimental Biology, 14, 9-14. https://doi.org/10.22364/eeb.14.02

[17] Ahmed, T.A.M., Mutwali, E.M. and Salih, E.A. (2019) The Effect of Seed Size and Burial Depth on the Germination, Growth and Yield of Sunflower (Helianthus annus L.). American Scientific Research Journal for Engineering, Technology, and Sciences, 53, 75-82. 